\title{
Türkiye'de Bölgesel Genç İşsizlik: Belirleyiciler Cinsiyete Göre Değişken mi?
}

\author{
Regional Youth Unemployment in Turkey: Do Determinants Vary by \\ Gender?
}

Mert TOPCU' $\odot$, Lütfi BiçiMVEREN² $\odot$

öz

İktisat teorisi, işsizliği en önemli makroekonomik sorunlardan biri olarak öne çıkartmaktadır. Üretim sürecine yapacağı katkılar göz önüne alındığında genç nüfusun işgücü piyasasına entegrasyonu, çalışma ekonomisi literatürünün temel odak noktalarından biridir. Bu doğrultuda Türkiye ekonomisinde çok sayıda çalışma genç işsizliğin dinamiklerini analiz etmeye odaklanmıştır. Ancak konuyu Türkiye'de cinsiyet bazında ve mikro temelli ele alan çalışma sayısı oldukça sınırlıdır. Bu noktadan hareketle çalışmada, 2014-2019 döneminde IBBS-2 düzeyinde yer alan 26 bölgede genç işsizliğin dinamikleri ve bu dinamiklerin cinsiyete göre farklılaşıp farklılaşmadığı incelenmektedir. Analiz sonuçları, kişi başına gelir değişkeninin hem toplam genç işsizliği hem de cinsiyete göre genç işsizliği negatif etkilediğini göstermektedir. Göreli kohort büyüklüğünün ve iç göçün her üç kategorideki genç işsizliği de pozitif etkilediği tespit edilmiştir. Enflasyon oranındaki artış genç kadın işsizliğini artırırken genç erkek işsizliğini azaltmaktadır. Benzer şekilde, ilk evlenme yaşındaki artış ise genç kadın işsizliğini artıırken, genç erkek işsizliğini azaltmaktadır. Bulgular genel olarak değerlendirildiğinde, belirleyicilerin genç kadın işsizliği üzerindeki etkisinin genç erkeklerdeki etkisinden daha büyük olduğu dikkat çekmektedir. Elde edilen sonuçlar, gençlerin işgücü piyasasına entegrasyonuna yönelik geliştirilecek politikalarda cinsiyet faktörünün göz ardı edilmemesi gerektiğine vurgu yapılmaktadır.

Anahtar kelimeler: Genç işsizlik, cinsiyet, türkiye, bölgesel analiz, panel veri

Jel Sınıflaması: E24, J11, R11

\author{
*Bu çalışma, 26-27 Ekim 2019 tarihinde \\ Kuşadası'nda düzenlenen 9. Uluslararası \\ Balkanlarda Sosyal Bilimler Kongresinde sunulan \\ "Türkiye'de Bölgesel Genç İşsizlik: Belirleyiciler \\ Cinsiyete Göre Değişken mi?" başlıklı bildirinin \\ revize edilmiş tam metin halidir. \\ 'Doç. Dr., Nevşehir Hacı Bektaş Veli Üniversitesi, \\ İktisadi ve İdari Bilimler Fakültesi, \\ Nevşehir, Türkiye \\ ${ }^{2}$ Doktora Öğrencisi, Nevşehir Hacı Bektaş Veli \\ Üniversitesi, Sosyal Bilimler Enstitüsü, \\ Nevşehir, Türkiye
}

ORCID: M.Y. 0000-0001- 8236-9810; L.B. $0000-0002-3177-0193$

\section{Sorumlu yazar/Corresponding author:} Mert TOPCU,

Nevşehir Hacı Bektaş Veli Üniversitesi, İktisadi ve İdari Bilimler Fakültesi, Nevşehir, Türkiye

E-posta/E-mail: merttopcu@nevsehir.edu.tr

\section{Başvuru/Submitted: 26.04.2020 \\ Revizyon Talebi/Revision Requested: 17.05.2020 \\ Son Revizyon/Last Revision Received: 24.05.2020 \\ Kabul/Accepted: 07.06 .2020}

Atıf/Citation: Topcu, M. \& Bicimveren, L. (2020). Türkiye'de bölgesel genç işsizlik: Belirleyiciler cinsiyete göre değişken mi?. Iktisat Politikası Araştırmaları Dergisi - Journal of Economic Policy Researches, 7(2), 51-67.

https://doi.org/10.26650/JEPR727340 


\begin{abstract}
Economic theory addresses unemployment as one of the crucial macroeconomic problems. Given the contributions to the production process, labor market integration of youth population is one of the main focuses of the labor economics literature. In this direction, a great number of studies have analyzed the dynamics of youth unemployment in the Turkish economy. However, a limited number of studies have investigated the issue in the case of Turkey with respect to gender using micro-level data. Given this knowledge, this study attempts to examine the determinants of the youth unemployment in 26 regions categorized under NUTS-2 over the period 2014-2019, and investigate whether those determinants vary by gender. Estimation results indicate that per capita income negatively affects both the total youth unemployment and youth unemployment by gender. Relative cohort size and internal migration positively affects all of the three youth unemployment categories. An increase in inflation rate increases youth female unemployment whereas youth male unemployment decreases with inflation. In addition, while an increase in age at first marriage increases youth female unemployment, it decreases youth male unemployment. Overall, the findings reveal that the impact that regional youth unemployment dynamics has on youth female unemployment is greater than on youth male unemployment. This study emphasizes that gender-based differences should be taken into account while developing policies towards the integration of youth into the labor market.
\end{abstract}

Keywords: Youth unemployment, gender, Turkey, regional analysis, panel data

Jel Classification: E24, J11, R11

\title{
EXTENDED ABSTRACT
}

Economic theory is in a broad consensus that enhancing youth population's prospects is the most effective way to achieve productive employment and sustainable economic growth. Therefore, every single country cares about the status of the younger population and invests in their human capital in order to reach these macroeconomic goals. Despite of all these efforts, however, youth unemployment rates have still been very high across the globe over the last two decades. For example, the average youth unemployment rate for Organization for Economic Cooperation \& Development countries as well as European Union (EU) member states was above $12 \%$, which was slightly higher than that for Turkey in the early 2000 s. In the late 2010s, however, Turkey experienced youth unemployment rates almost over $20 \%$, which was higher than the averages experienced by the EU and OECD countries. Given this prominence, it is very important to investigate the dynamics of youth unemployment to shed light on what drives the youth labor force to become unemployed. In this direction, there exist a great number of studies examining the dynamics of youth unemployment, not only for multi-country cases (see, for example: Awad, 2019; Jimeno and Rodriguez-Palenzuela, 2003; among others), but also for those in the case of Turkey (see, for example: Kabaklarli and Gur, 2011; Sever and Igdeli, 2018; among others). Although the literature in the case of Turkey is very well-documented, we still do not know much about what the dynamics are once the issue is using micro-level data. To the best of our knowledge, Didin Sonmez and Ozerkek (2018) is the only study that examines this issue in Turkey from the regional point of view. 
In terms of market structure, Turkey looks like a men-dominated labor market where only one third of women participate in. When the split between youth female unemployment and youth male unemployment is examined, in addition, it is very apparent that average unemployment of youth females is higher than that of youth males. It is therefore likely to expect that regional unemployment dynamics in Turkey could vary by gender.

Given the aforementioned information, the goal of this study is to investigate the determinants of youth unemployment in 26 regions categorized under NUTS-2 in order to find out whether those determinants vary by gender. To this end, we use annual observations spanning from 2014 to 2019 within a regional panel framework.

Having found that all the variables in the system are $\mathrm{I}(0)$, we estimate the slope coefficients using regression with Driscoll-Kraay standard errors, proposed by Driscoll and Kraay (1998). The error structure in this estimator is assumed to be heteroskedastic, autocorrelated up to some lag, and possibly correlated between the cross sections. Given that this approach does not limit the number of cross sections, it becomes very feasible even when the number of cross sections is much larger than the time dimension. Estimation results indicate that per capita income negatively affects both total youth unemployment and youth unemployment by gender. Relative cohort size and internal migration positively affects all of the three youth unemployment categories. An increase in the inflation rate increases youth female unemployment whereas youth male unemployment decreases with inflation. In addition, while an increase in age at first marriage increases youth female unemployment, it decreases youth male unemployment.

Overall, the findings reveal that the impact that regional youth unemployment dynamics has on youth female unemployment is greater than on youth male unemployment. As a crucial policy recommendation, this study emphasizes that gender-based differences should be taken into account while developing policies towards the integration of youth into the labor market. In order to eliminate the exclusion effect that the findings address, for instance, youth female-oriented employment policies should be supported much more. Other potential policy implications pertaining to the empirical results are also discussed in the study.

Disclaimer: This research paper should not be reported as representing the views of the named institutions the authors are associated with. The views expressed here are those of the authors and do not necessarily represent those of their affiliated institutions and policies. 


\section{Giriş}

Temel makroekonomik problemlerin başında gelen işsizlik olgusu, özellikle genç işsizliğinin birçok ülkede önemli bir problem haline gelmesiyle son dönemlerde yerini gençler üzerinden süregelen tartışmalara bırakmıştır. İşgücü piyasası kapsamında "genç" kavramı, 15-24 yaş aralığındaki nüfusu ifade etmektedir (O’higgins, 1997). Uluslararası Çalışma Örgütü (ILO), genç işsizlik oranını 15-24 yaş arasındaki işsiz nüfusun aynı yaş aralığındaki işgücüne oranı olarak tanımlamaktadır. ILO'nun bu tanımı, Türkiye de dahil olmak üzere $\mathrm{AB}, \mathrm{OECD}$ gibi birçok ülke ve topluluk tarafından referans alınmaktadır. $\mathrm{Bu}$ tanımdan yola çıkarak genç işsizliğin sadece ekonomik değil, aynı zamanda sosyal boyutlarının da çok önemli olduğu kuşkusuz bir gerçektir. Bu kapsamda eğitim sürecini tamamlayan genç işgücünün istihdam altına alınamaması, işgücü piyasasının en önemli problemlerinden biri olarak dikkat çekmektedir.

\section{Grafik 1. AB, OECD ve Türkiye'de Genç İşsizlik Oranları}

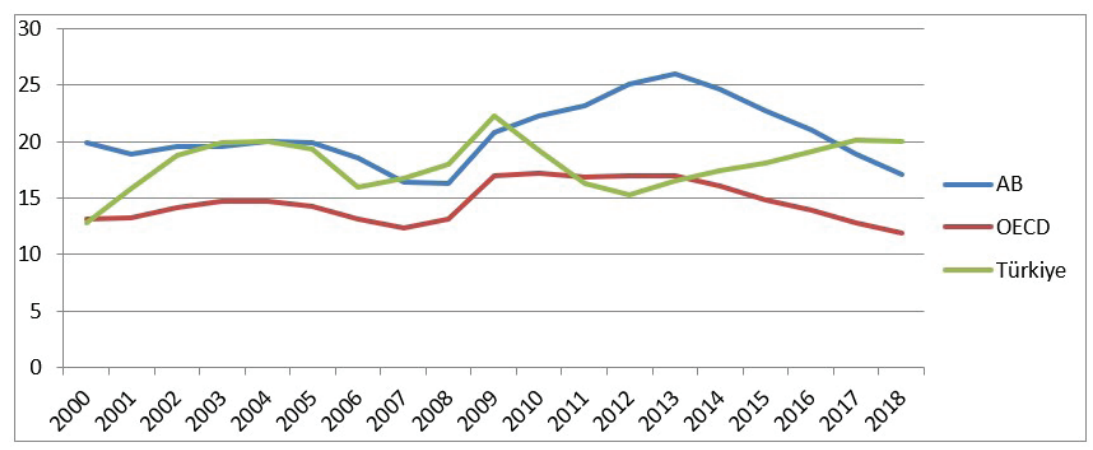

Kaynak: Dünya Bankası, Dünya Kalkınma Göstergeleri Veritabanı

Grafik 1, küresel ölçekte iki önemli aktör olan AB ve OECD ülkelerindeki genç işsizlik oranları ile Türkiye'nin genç işsizlik oranını göstermektedir. 21. yüzyılın başından itibaren sürekli \%12 bandının üzerinde seyreden ortalama, genç işsizliğin küresel düzeyde ciddi bir sorun olduğuna işaret etmektedir. Grafiğin işaret ettiği en önemli bulgulardan biri, 2013 yılından itibaren Türkiye'deki genç işsizlik oranlarının, AB ve OECD ortalamalarındaki trendin tersi yönünde hareket etmesidir. Bu veriler, genç işsizliğin ülkemizdeki önemine işaret etmektedir. 


\section{Grafik 2. Türkiye'de İșsizlik vs. Genç İșsizlik}

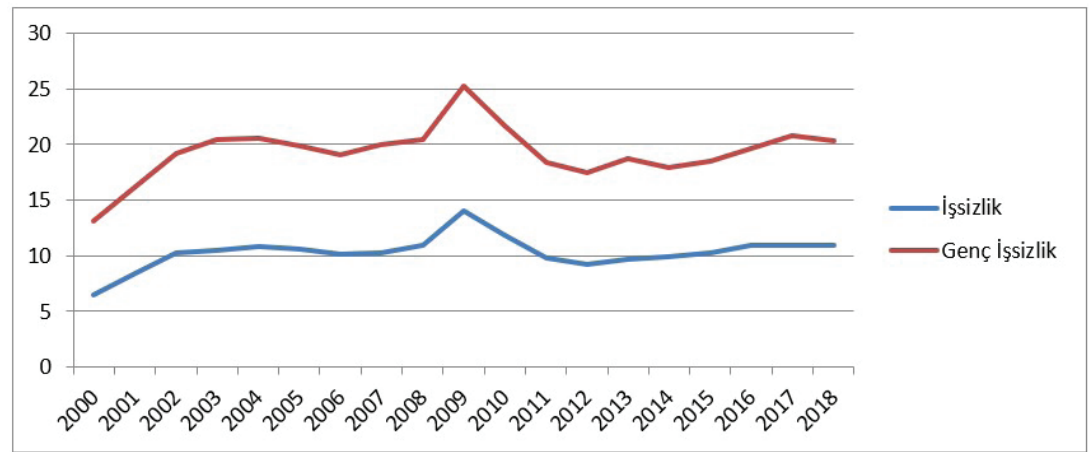

Kaynak: Dünya Bankası, Dünya Kalkınma Göstergeleri Veritabanı

Grafik 2, ülkemizde genç işsizlik oranları ile işsizlik oranlarının seyrini kıyaslamaktadır. Grafiğe göre genç işsizlik oranı, toplam işsizlik oranından oldukça yüksek seyretmektedir. $\mathrm{Bu}$ bilgi, genç işsizliğin genel işsizlik oranı içerisindeki rolünü gözler önüne sermektedir. Buna göre, genç işsizliğe yönelik geliştirilecek politikalar, toplam işsizlik oranının da düşmesine önemli katkı sağlayacaktır. Literatürde Türkiye' de genç işsizliğin belirleyicilerine odaklanan çok sayıda çalışma yer almaktadır ve bu çalışmalardan bir çoğu genç işsizliği makro boyutta araştırmaktadır (bknz: literatür taraması).

\section{Grafik 3. Türkiye'de Genç İşsizlik Oranlarının Cinsiyete Göre Dağılımı}

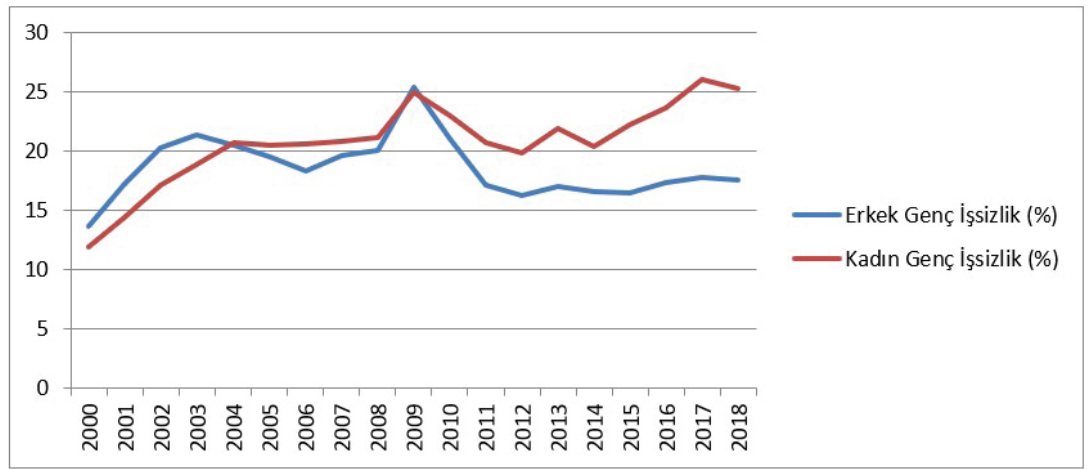

Kaynak: TÜIK, İșgücü İstatistiki Göstergeleri Veritabanı 
Grafik 3 ise Türkiye'deki genç işsizlik oranının cinsiyete göre değişimini göstermektedir. Grafikte 2000'li yılların başlarında genç erkek işsizlik oranının genç kadın işsizlik oranından yüksek olduğu görülmektedir. Ancak bu durum yıllar içerisinde dalgalanma göstermiş, 2007/08 küresel krizinden sonra genç kadın işsizliği genç erkek işsizliğini geçmiştir. Yakın dönemde ise her iki genç işsizlik türünün de artış gösterdiği ve aradaki farkın açılarak seyrettiği gözlemlenmektedir. Bu gerçekten hareketle, genç işsizlik belirleyicilerinin cinsiyet bazında farklılık gösterebileceği ve literatürde toplam genç işsizliğin dinamiklerini tespit eden çalışmaların toplamın yanlılı̆̆ı (aggregation bias) sorununa neden olabileceği düşünülmektedir. Bu noktada mevcut çalışma, bölgesel genç işsizliğin belirleyicilerinin cinsiyete göre farklılık gösterip göstermediğini incelemeyi amaçlamaktadır. Bu amaç doğrultusunda çalışmada ortaya sürülen temel hipotez "bölgesel genç işsizliği etkileyen faktörlerin cinsiyet bazında değişken olabileceği” şeklinde kurgulanmıştır.

Giriş bölümünü takiben ikinci bölümde teorik çerçeve çizilecek, üçüncü bölümde ilgili literatür taranacak, dördüncü bölümde ekonometrik analizde faydalanılacak model ve veri tanıtılacak, beşinci bölümde yöntem ve bulgular sunulacak, son bölümde ise politika çıkarımları tartışılıp genel bir değerlendirme yapılarak çalışma sonuçlandırılacaktır.

\section{Teorik Çerçeve}

Genç işsizliğin belirleyicilerini araştıran çalışmaların birçoğu, işsizliği etkileyen temel faktörlerin genç işsizliğin de belirleyicileri olduğuna vurgu yapmaktadır. O’higgins (1997), genç işsizliğin gençlere özel spesifik belirleyicilerden ziyade toplam talep faktörü ile alakalı olduğunu belirtmektedir. Bu noktada iktisat teorisi işsizliğin temel belirleyicisi olarak fiyatlar ve gelir seviyesini ön plana çıkartırken, çalışma ekonomisi literatürü de bu iki faktörün genç işsizlik üzerindeki etkisine vurgu yapmaktadır. Okun (1962) tarafindan ortaya konulmuş olan teoriyi genç işsizlik ile revize eden çalışmalar, üretim seviyesinin genç işsizlik üzerinde anlamlı etkisi olduğu belirtmektedir (Brooks ve Pradhan, 2015; Dunsch, 2016; Butkus ve Seputiene, 2019). Buna göre artan üretim ve dolayısıyla gelir seviyesinin Okun yasası çerçevesinde işgücü talebini artırarak genç işsizliği azaltması beklenmektedir. Diğer taraftan, Phillips (1958) eğrisi teorisinin ortaya koyduğu kısa dönemli işsizlikenflasyon değiştokuşu, fiyat artışlarının genç işsizlik oranını da etkileyebileceğine işaret etmektedir. İktisat teorisinde toplam talebin artması ile yükselen fiyatların kısa dönemde işgücü talebinde artışa neden olarak işsizlik oranlarını arttırması beklenmektedir. Bu analizi genç işgücü üzerinden revize eden Marelli, Choudhry ve Signorelli (2013), gerçekleşen fiyat seviyesinin beklenen fiyat seviyesini aşması durumunda reel ücretlerin sözleşme dönemindeki beklenen ücretlerden daha düşük olabileceğini; bu durumda ortaya çıkan işgücü talebi sonucu da genç işsizliğin azalabileceğini ifade etmektedir. 
Didin Sönmez ve Özerkek (2018), gençlerin mesleki tecrübe sebebiyle yetişkin işgücüne göre daha dezavantajlı olduğunu ve sınırlı istihdam olanakları göz önüne alındığında yetişkin işgücü ile rekabet etmek zorunda olduğunu belirtmektedir. İşsizlik teorilerini açıklayan modellerden İçeridekiler-Dışarıdakiler hipotezi, firmaların mevcut çalışanlarını (içeridekiler) işten çıkarma maliyetlerinin, işsizleri (dışarıdakiler) işe alıp eğitme maliyetinden daha yüksek olduğunu düşünmeleri sonucunda içeridekilerin daha avantajlı bir durumda olduğuna vurgu yapmaktadır (Lindbeck ve Snower, 2001). Bu nedenle göreli kohort büyüklügünün artması ile piyasaya yeni giren gençlerin genellikle işsiz kalma eğiliminde olduğu belirtilmektedir (Korenman ve Neumark, 2000; Gomez-Salvador ve Leiner-Killinger, 2008; Moffat ve Roth, 2014).

Borjas (1994), göçün iktisadi etkilerinin değişken bazında, dönemsel ve coğrafik olarak değişken olduğunu ifade etmektedir. Todaro (1969) ve Harris ve Todaro (1970), bulundukları bölgelerdeki işsizlik oranının yüksek olduğunu düşünen işsiz bireylerin ücretin yüksek olduğu bölgelere göç etme isteğinde olduğunu, bu durumun da genel istihdam seviyesini azaltacağını belirtmektedir. Greenwood ve McDowell (1986) ise göçün ücretler ve işgücü üzerindeki etkisinin işgücü arzının ve işgücü talebinin esnekliği ile göç miktarıyla alakalı olduğunu ifade etmektedir. İşgücü arzı ve talebinin inelastik olduğu durumlarda alınan göçün yerel ücretleri azalttığını; yerel işgücü arzının elastik, işgücü talebinin inelastik olduğu durumlarda ise göçle gelen işgücünün yerel işgücünün yerini alma ihtimalini artırdığını belirtmektedir. Türkiye'de kırdan kentlere göç edenlerin önemli bir kısmı işsizlik nedeniyle göç etmektedir (Şen, 2014). $\mathrm{Bu}$ durumun da göç alan bölgede İçeridekiler-Dışarıdakiler teorisi gereği işsizlik oranlarını arttırması muhtemeldir. Çelik ve Arslan (2018) ise, Türkiye'de göçün sadece genel işsizlik oranları değil genç işsizlik oranlarını da artırdığını tespit etmiştir. Ayrıca göçün işsizlik üzerindeki etkilerini cinsiyete göre inceleyen çalışmalar, göçün işsizliği erkeklere kıyasla kadınlarda daha olumsuz etkilediğini göstermektedir (Longhi, Nijkamp ve Poot, 2006; Jean ve Jiménez, 2011). Ayrıca, iktisadi belirleyiciler ve göç dışında bir takım sosyo-demografik faktörler de genç işsizlik üzerinde anlamlı etkilere sahiptir. Terzo ve Giaconia (2019), cinsiyet, medeni durum ve ailevi durumlar gibi göstergelerin gençlerin sosyal ve ekonomik kararlarını etkilemek suretiyle genç işsizlik oranını değiştirebildiğini belirtmektedir. Isengard (2003), evli olan gençlerin mobilite kısıtı nedeniyle bekar gençlere kıyasla işsizlik riskinin daha yüksek olduğunu ortaya koymaktadır.

\section{Literatür Taraması}

Genç nüfusun karşılaştı̆̆ işsizlik olgusu, günden güne önemini arttırarak 2000'lerin başından itibaren ekonomistlerin odak noktası haline gelmiştir. Bu önemden yola çıkarak, sorunun hangi değişkenlerle ilişkili olduğunu konu alan literatüre değinmek, çalışmanın literatürdeki hangi boşluğu hedef aldığının belirlenmesi açısından faydalı olacaktır. Jimeno 
ve Rodriguez-Palenzuela (2003), 19 OECD ülkesinde 1960-1996 döneminde demografik, kurumsal ve makroekonomik faktörler ile genç işsizlik arasındaki ilişkiyi incelemiştir. Araştırmadan elde edilen sonuçlar, ülkelerin genç nüfusunun, makroekonomik şokların ve işgücü piyasası kurumlarının spesifik yaşlardaki işsizlik oranları üzerinde etkili olduğunu göstermektedir. Choudry, Marelli ve Signorelli (2012), yüksek gelirli 70 ülkede 1985-2005 döneminde krizlerin genç işsizlik üzerindeki etkisini incelemiştir. Çalışmadan elde edilen bulgulara göre gençlerin yaşlılara kıyasla istihdamdaki konjonktürel dalgalanmalardan daha fazla etkilendiği tespit edilmiştir. Demidova ve Signorelli (2012), 2000-2009 döneminde Rusya'da 75 ayrı bölgede genç işsizliğin belirleyicilerini araştırdıkları çalışmada hem iktisadi hem de demografik değişkenlerin genç işsizlik üzerinde etkili olduğunu belirtmiştir. Ayrıca, 2008/09 finansal krizinin de genç işsizlik üzerinde anlamlı bir etkisinin olduğu tespit edilmiştir. Anyanwu (2014), 1980-2010 döneminde Afrika'da genç işsizliğin belirleyicisi olarak bölge içi ticaretin yanında ekonomik büyüme, yüksek kentleşme ve demokratikleşme gibi unsurların da olduğunu ifade etmiştir. Pastore ve Giuliani (2015), 1970-2013 döneminde seçilmiş 21 ülkeden oluşan panelde genç işsizliğin belirleyicilerini araştırmış ve kişi baş1 gelir, ekonomik büyüme ve aktif işgücü piyasası politikalarının genç işsizliğini azalttı̆̆ını; istihdam koruma endeksinin ise genç işsizliğini artırdığını belirtmiştir. Ghoshray, Ordonez ve Sala (2016), 1993-2013 döneminde Avrupa'daki 15 ülke üzerine yaptıkları analiz sonucunda eğitim sistemi göreli performansının genç işsizliği üzerinde etkili olduğunu, kapsamlı işgücü piyasası reformlarının ise genç işsizliğini çözmede yeterince etkin olmadığını ifade etmektedir. Cvecic ve Sokolic (2018), 2005-2014 döneminde 27 Avrupa Birliği ülkesinde gelir, enflasyon ve eğitim seviyesinin genç işsizliği azalttığını, aktif işgücü piyasası politikaları harcamaları içerisindeki kamu harcama payının artmasının ise genç işsizliği artırdığını ifade etmiştir. Awad (2019), 1994-2013 döneminde 50 Afrika ülkesinden oluşan panelde ticari açıklık ve işgücü piyasası regülasyonlarının genç işsizliği azalttığını, kentleşmenin ise genç işsizliği artırdığını tespit etmiştir. Balcı İzgi ve Konu (2019), 1997 2017 döneminde BRICS ülkeleri ve Türkiye'den oluşan panelde genç işsizliği cinsiyete göre ayırmış ve cinsiyete göre genç işsizliğin belirleyicilerini incelemiştir. Bulgular erkek genç işsizliğin kadın genç işsizliği üzerinde, kadın genç işsizliğinin de erkek genç işsizliği üzerinde pozitif etkisini olduğunu doğrulamaktadır. Ayrıca, nüfus büyüme oranı ve tüketim harcamalarındaki artışlar ise erkek genç işsizliğini negatif etkilemektedir.

İşgücü piyasası ile alakalı Türkiye ekonomisi üzerine yapılan çalışmalar, çok geniş yelpazede farklı konulara değinmektedir. Bunlar arasında işgücünün belirleyicileri, kadın istihdamı ve işgücü, işgücünün dışında kalanların durumu gibi konular bulunmaktadır (Göksel, 2013; Bölükoğlu, 2018; Topcu, 2018). Ancak genç işsizliğin belirleyicileri ile ilgili yapılan çalışmaların görece kısıtlılığı söz konusudur (literatür taraması için bknz: Çetinkaya, 2010). Kabaklarlı ve Gür (2011), 2005-2010 dönemide genç işsizlik ile reel gelir, reel yatırımlar, 
verimlilik ve enflasyon değişkenleri arasındaki uzun dönemli ilişkinin var olduğu sonucuna ulaşmıştır. Eşbütünleşik denklem tahminine göre enflasyon ve verimlilik değişkenleri genç işsizlik oranlarını pozitif etkilerken, yatırımlar ve gelir ise genç işsizlik oranlarını negatif etkilemektedir. Günaydın ve Çetin (2015), 1988-2013 döneminde kişi başına reel gelir, ticari açıklık, enflasyon ve doğrudan yabancı sermayenin genç işsizlik üzerindeki etkisini araştırmıştır. Elde edilen bulgulara göre, ticari açıklık, doğrudan yabancı sermaye ve kişi başına reel gelir değişkenleri ile genç işsizlik arasında negatif bir ilişkinin varlığı tespit edilmiştir. Bayrak ve Tatlı (2016), 1988-2014 döneminde genç işsizlik oranı ile üretici fiyat endeksi, yüksek öğretimde okullaşma oranı ve ekonomik büyüme değişkenleri arasındaki ilişkiyi tespit etmeye çalışmıştır. Elde edilen uzun dönemli katsayılara göre üretici fiyat endeksi ve yükseköğretimde okullaşma oranı, genç işsizlik oranını negatif olarak etkilemektedir. Büyüme oranı ise uzun dönemde genç işsizlik oranını istatistiksel olarak anlamlı bir biçimde etkilememektedir. Erikli (2016), 2011-2015 döneminde genç işsizliğin nedenlerini düzgün iş bulamama, istihdam güvencesinin olmayışı ve eğitim durumu gibi faktörlere bağlamıştır. Arı ve Yıldız (2017), 1988-2015 döneminde genç işsizliğin belirleyicilerini araştırmış ve yüksek öğretimde okullaşma oranı ile nüfus artış hızı değişkenlerinin genç işsizlik değişkeni üzerinde uzun dönemde pozitif bir etkisinin olduğunu tespit etmiştir. Çondur ve Şimşir (2017), 19912016 döneminde eğitim harcamaları ve ekonomik büyümenin genç işsizlik üzerindeki etkisini araştırmış ve eğitim harcamalarındaki artışın genç işsizliği artırdığını, ekonomik büyümedeki artışların ise genç işsizliği azalttığını belirtmiştir. Güney ve Balkaya (2018), 2006-2017 döneminde yatırım ve transfer harcamalarının uzun dönemde genç işsizliği artırdığını, ticari açıklığın ise uzun dönemde genç işsizliği azalttığını tespit etmiştir. Sever ve İğdeli (2018), 1988-2016 döneminde genç işsizliği etkileyen faktörleri incelediği çalışmasında iktisadi krizlerin genç istihdamı azalttığını, kişi başı gelirdeki artışların ise uzun dönemde genç işsizliği azaltacağını belirtmiştir. Ayrıca, yetişkin işsizliğinin, ticari açıklığın ve doğrudan yabancı yatırımların uzun vadede genç istihdamı olumsuz etkilediği gözlenmiştir. Karahan Dursun (2019), 2005-2018 döneminde doğrudan yabancı yatırımların farklı eğitim düzeylerindeki istihdam seviyeleri üzerindeki etkisini çalışmasında doğrudan yabancı yatırımların sadece meslek lisesi ve yüksek öğretim genç istihdamı üzerinde pozitif etkiye sahip olduğunu ve bu etkinin en çok yüksek öğretim mezunu genç iş gücünde görüldüğünü ifade etmiştir.

Türkiye'de genç işsizliğin belirleyicileri üzerine yapılan çalışmalar genellikle makro boyuttadır. Ancak genç işsizliğin belirleyicilerini bölge bazında araştıran bilgimiz dahilindeki tek çalışma Didin Sönmez ve Özerkek (2018)' dir' . Didin Sönmez ve Özerkek

\footnotetext{
${ }^{1}$ Özer ve Topal (2017) İBBS-2 düzeyinde çalışmış olmasına rağmen çalışma genç işsizliğin belirleyicilerini değil, genç işsizliğin etkilerini araştırmıştır. Özer ve Topal (2017), 2004-2016 döneminde bölgesel olarak genç işsizliğin sosyoekonomik değişkenler üzerindeki etkisini incelemiş ve genç işsizlikteki artışların suç, göç, intihar ve boşanma olgularını artırdığını tespit etmiştir.
} 
(2018), İBBS-2 düzeyinde genç işsizliğin nedenlerini makroekonomik ve demografik değişkenler yardımıyla açıklamıştır. Çalışmadan elde edilen sonuçlara göre kohort büyüklüğü ve enflasyon oranın genç işsizliği negatif etkilerken, kişi başı gelir ve ticari açıklık ise genç işsizliği istatistiki olarak anlamlı bir şekilde etkilememektedir.

\section{Model ve Veri}

Çalışmanın amacı, Türkiye ekonomisinde bölgesel genç işsizlik dinamiklerini araştırmaktadır. Mevcut literatürü takiben çalışmada bölgesel genç işsizlik; bölgesel enflasyon oranının, bölgesel kişi başına gelirin, bölgesel göreli kohort büyüklüğünün ve bölge bazında alınan göçün bir fonksiyonu olarak tanımlanmıştır.

$$
y u=f(\pi, y, \mathrm{coh}, \mathrm{im})
$$

Denklem (1)'de ifade edilen bu fonksiyonda yu bölgesel genç işsizliğii, $\pi$ bölgesel enflasyon oranını, y bölgesel kişi başına geliri, coh bölgesel göreli kohort büyüklüğünü² ve im ise bölge bazında alınan ülke içi göçü simgelemektedir. Çalışmada, İBBS (İstatistiki Bölge Birimleri Sınıflandırması) Düzey 2'de yer alan 26 bölgeye ait 2014-2019 dönemini kapsayan yıllık gözlemler kullanılmıştır. Denklem (2), bir önceki denklemin panel veri formatında açılmış halini yansıtmaktadır:

$$
\ln y u_{i t}=\alpha_{0}+\alpha_{1} \ln \pi_{i t}+\alpha_{2} \ln y_{i t}+\alpha_{3} \operatorname{lncoh}_{i t}+\alpha_{4} \operatorname{lnim}_{i t}+\varepsilon_{i t}
$$

burada $\mathrm{i}$ indisi İBBS-2 düzeyine göre suralanan bölgeleri $(\mathrm{i}=1, \ldots ., 26), \mathrm{t}$ indisi zaman periyodunu $(\mathrm{t}=2014, \ldots . .2019), \varepsilon$ terimi ise rassal hata terimini göstermektedir. $a_{0}$ sabit terimi simgelerken, $a_{1}, a_{2}, a_{3}$ ve $a_{4}$ ise sırasıyla bölgesel enflasyon oranının, bölgesel kişi başına gelirin, bölgesel göreli kohort büyüklügünün ve bölgesel iç göçün katsayılarını temsil etmektedir.

Çalışmada cinsiyet bazında da bölgesel genç işsizliğin belirleyicileri de araştırılmıştır. Buna göre, denklem (2)' de sunulan bağımsız değişkenlere ilave olarak ortalama ilk evlenme yaşı da modele dahil edildiğinde:

$$
\begin{aligned}
& \operatorname{lnwyu}_{i t}=\beta_{0}+\beta_{1} \ln _{i t}+\beta_{2} \ln _{i t}+\beta_{3} \operatorname{lnwco}_{i t}+\beta_{4} \operatorname{lnim}_{i t}+\beta_{5} \operatorname{lnwmage}_{i t}+\mu_{i t} \\
& \mathrm{ve} \\
& \operatorname{lnmyu}_{i t}=\gamma_{0}+\gamma_{1} \ln _{i t}+\gamma_{2} \operatorname{lny}_{i t}+\gamma_{3} \operatorname{lnmco}_{i t}+\gamma_{4} \operatorname{lnim}_{i t}+\gamma_{5} \operatorname{lnmmage}_{i t}+v_{i t}
\end{aligned}
$$

olarak yazılabilir. Denklem (3)’te wyu bölgesel genç kadın işsizliğini, wcoh kadınlar için bölges $\ell$ göreli kohort büyüklüğünü ${ }^{3}$, wmage kadınlar için bölgesel ortalama ilk evlenme

\footnotetext{
${ }^{2}$ Didin Sönmez ve Özerkek (2018)'in bölgesel analizini takiben bu çalışmada göreli kohort büyüklüğü, genç işgücünün işgücü içerisindeki payı şeklinde tanımlanmıştır.

${ }^{3}$ Kadınlar için kohort büyüklüğü, toplam kadın işgücü içerisindeki genç kadın işgücünü ifade etmektedir.
} 
yaşını, rassal hata terimini; denklem (4)'te ise myu bölgesel genç erkek işsizliğini, mcoh erkekler için bölgesel göreli kohort büyüklüğünü ${ }^{4}$, mmage erkekler için bölgesel ortalama ilk evlenme yaşını, $v$ rassal hata terimini yaşını temsil etmektedir. $\beta$ ve $\gamma$ katsayıları ise sırasıyla kadınlar ve erkekler için bağımsız değişkenlerdeki değişmelerin bağımlı değişken üzerindeki etkisini ölçen katsayılardır. Tablo 1, çalışmada kullanılan değişkenlerin açıklamalarını ve veri kaynaklarını göstermektedir. Elde edilen katsayıların esneklik için yorumlanabilmesi için değişkenlerin tamamı doğal logaritmaları alınarak modele dahil edilmiştir.

Tablo 1: Çalışmada Kullanılan Değişkenlerin Açıklamaları ve Kaynakları.

\begin{tabular}{|c|c|c|}
\hline Değişkenler & Açıklama & Kaynak \\
\hline Genç İşsizlik & Bölgesel Genç İşsizlik (\%) & TÜİK İşgücü İstatistikleri \\
\hline Genç Kadın İşsizliği & Bölgesel Genç Kadın İşsizliği (\%) & TÜİK İşgücü İstatistikleri \\
\hline Genç Erkek İşsizliği & Bölgesel Genç Erkek İşsizliği (\%) & TÜİK İşgücü İstatistikleri \\
\hline Enflasyon $(\ln \pi)$ & $\begin{array}{l}\text { Bölgesel Enflasyon oranı }(2003=100, \text { Bir } \\
\text { önceki yılın aynı ayına göre değişim, \%) }\end{array}$ & $\begin{array}{l}\text { TÜİK Enflasyon ve Fiyat İstatis- } \\
\text { tikleri }\end{array}$ \\
\hline Kişisel Gelir (lny) & Bölgesel Kişi Başı GSYH (2009=100, TL) & TÜİK Ulusal Hesaplar İstatistikleri \\
\hline $\begin{array}{l}\text { Göreli Kohort Büyüklüğü } \\
\text { (lncoh) }\end{array}$ & Bölgesel Genç İş̧gücü (\%Bölgesel İşgücü) & TÜİK İşgücü İstatistikleri \\
\hline $\begin{array}{l}\text { Kadın Kohort Büyüklüğü } \\
\text { (lnwcoh) }\end{array}$ & $\begin{array}{c}\text { Bölgesel Genç Kadın İşgücü (\% Bölgesel } \\
\text { Kadın İşüüü) }\end{array}$ & TÜİK İşgücü İstatistikleri \\
\hline $\begin{array}{l}\text { Erkek Kohort Büyüklüğü } \\
\text { (lnmcoh) }\end{array}$ & $\begin{array}{c}\text { Bölgesel Genç Erkek İşgücü (\% Bölgesel } \\
\text { Erkek İşgücü) }\end{array}$ & TÜİK İşgücü İstatistikleri \\
\hline Bölge İçi Göç (lnim) & Bölgesel Olarak Alınan Ülke İçi Göç & TÜİK Göç İstatistikleri \\
\hline $\begin{array}{l}\text { Kadınlarda Ortalama İlk } \\
\text { Evlenme Yaşı (lnwmage) }\end{array}$ & $\begin{array}{c}\text { Bölgesel Bazda Kadının Ortalama İlk } \\
\text { Evlenme Yaşı }\end{array}$ & $\begin{array}{c}\text { TÜİK Nüfus ve Demografi İstatis- } \\
\text { tikleri }\end{array}$ \\
\hline $\begin{array}{l}\text { Erkeklerde Ortalama İlk } \\
\text { Evlenme Yașı (lnmmage) }\end{array}$ & $\begin{array}{c}\text { Bölgesel Bazda Erkeğin Ortalama İlk } \\
\text { Evlenme Yașı }\end{array}$ & $\begin{array}{c}\text { TÜİK Nüfus ve Demografi İstatis- } \\
\text { tikleri }\end{array}$ \\
\hline
\end{tabular}

\section{Yöntem ve Bulgular}

Granger ve Newbold (1974), durağan olmayan serilerle tahmin yapılmasının tutarsız sonuçlar üreteceğini belirtmektedir. Bu nedenle katsayı tahmini öncesinde serilerin birim kök analizinin yapılması gerekmektedir. Geleneksel panel veri literatüründe yaygın olarak kullanılan testler Levin, Lin ve Chu (2002) tarafından geliştirilen LLC testi ile Im, Pesaran ve Shin (2003) tarafından geliştirilen IPS testleridir. Denklem (5), LLC testinin matematiksel versiyonunu göstermektedir:

$$
\Delta y_{i t}=\mu_{i}+\phi_{t}+\rho y_{i t-1}+\sum_{j=1}^{k} \delta_{j} \Delta y_{i t-j}+\varepsilon_{i t}
$$

Homojen bir yapıda çalışan LLC testi, paneli oluşturan tüm birimlere ait eğim

\footnotetext{
${ }^{4}$ Erkekler için kohort büyüklüğü, toplam erkek işgücü içerisindeki genç erkek işgücünü ifade etmektedir.
} 
parametrelerinin aynı olduğunu varsaymaktadır. LLC testinde "panel veri setinin birim kök içerdiği $(\rho=0)$ " şeklinde kurulan boş hipotez, "panel veri setinin birim kök içermediği $(\rho \neq 0)$ " şeklinde kurulan alternatif hipoteze karşı sınanmaktadır.

Tüm eğim parametrelerinin homojen olduğu LLC testinin aksine, Im, Pesaran ve Shin (2003),paneli oluşturan tüm birimlere ait eğim parametrelerinin birbirinden farklı olabildiği $\left(\mathrm{p}_{1}=\mathrm{p}_{2}=\ldots=\mathrm{p}_{\mathrm{i}}\right)$ bir test istatistiği geliştirmiştir. IPS testinde "paneli oluşturan tüm birimlerde birim kök içerdiği $\left(\rho_{\mathrm{i}}=0\right)$ )" şeklinde kurulan boş hipotez, "paneli oluşturan en az bir yatay kesitin birim kök içermediği $\left(\rho_{\mathrm{i}} \neq 0\right)$ ” şeklinde kurulan alternatif hipoteze karşı sınanmaktadır 5 .

Tablo 2: Panel Birim Kök Testi.

\begin{tabular}{lcc}
\hline Değişkenler & LLC & IPS \\
\hline lnyu & $<0.01$ & $<0.01$ \\
lnywu & $<0.01$ & $<0.01$ \\
$\operatorname{lnymu}$ & $<0.01$ & $<0.01$ \\
$\ln \pi$ & $<0.01$ & $<0.01$ \\
$\ln y$ & $<0.01$ & $<0.01$ \\
lncoh & $<0.01$ & $<0.01$ \\
lnwcoh & $<0.01$ & $<0.01$ \\
lnmcoh & $<0.01$ & $<0.01$ \\
Inim & $<0.01$ & $<0.01$ \\
lnwmage & $<0.01$ & $<0.01$ \\
lnmmage & $<0.01$ & $<0.01$ \\
\hline
\end{tabular}

Not: Raporlanan değerler, test istatistiklerine ait olasılık (probability) değerleridir. Her iki testte de maksimum gecikme sayısı, Schwarz (SIC) bilgi kriteri göz önüne alınarak 1 olarak belirlenmiştir. Testler sabit terim içermektedir.

Tablo 2, LLC ve IPS birim kök testlerine ait sonuçları göstermektedir. Her iki test sonuçları da "serilerin birim kök içermediği”" şeklinde kurulan boş hipotezin \%1 anlamlılık düzeyinde reddedilmesi gerektiğine işaret etmektedir. Buna göre tüm değişkenlerin seviyelerinde durağan olduğu sonucuna ulaşılmaktadır. Sistemdeki tüm değişkenlerin durağan olması, regresyon analizi açısından bir kısıtlama olmadığına işaret etmektedir. Regresyon tahmini, güçlendirilmiş standart hataları tahmin etmek için geliştirilmiş Driscoll ve Kraay (1998) metodu ile gerçekleştirilecektir. Bu tahminciden elde edilen sonuçlar, hata terimlerinin değişen varyans, belli bir gecikme seviyesine (MA(q)) kadar otokorelasyon ve yatay kesit bağımlılığı gibi sorunlarına karşı güçlendirilmiş yapıdadır. Standart hataların tahmin edilmesini sağlayan bu parametrik olmayan yöntem, paneli oluşturan yatay kesitlerin sayısı ile ilgili bir kısıtlamaya gitmemektedir. Bu nedenle de, panelin birim boyutunun zaman boyutundan çok daha fazla olduğu panellerde bile rahatlıkla uygulanabilmektedir.

Tablo 3, havuzlanmış En Küçük Kareler (pooled OLS) yöntemine dayanan Driscoll ve

\footnotetext{
${ }^{5}$ IPS testinin matematiksel versiyonu LLC testi ile aynı olduğu için, IPS testinin denklemi ayrıca sunulmamıştır.
} 
Kraay (1998) tahmincisinden elde edilen sonuçları göstermektedir. Elde edilen bulgulara göre enflasyon oranındaki \%1'lik artış; toplam genç işsizliği \%0,147, genç erkek işsizliğini \%0,155 azaltırken, genç kadın işsizliğini \%0,142 artırmaktadır. Kişi başına gelirdeki \%1'lik artış; toplam genç işsizliği \%0,198, genç kadın işsizliğini \%0.144, genç erkek işsizliğini ise $\% 0,233$ azaltmaktadır. Göreli kohort büyüklüğündeki \%1'lik artış toplam genç işsizliğini \%0.066, kadınlar için göreli kohort büyüklüğündeki \%1'lik artış genç kadın işsizliğini \%0.083, erkekler için göreli kohort büyüklüğündeki \%1'lik artış ise genç erkek işsizliğini \%0.043 artırmaktadır. Alınan bölge içi göçte gerçekleşen \%1'lik artış; toplam genç işsizliğini \%0,101, genç kadın işsizliğini \%0,173, genç erkek işsizliği ise \%0,097 artırmaktadır. Son olarak, kadınlarda ortalama ilk evlenme yaşı \%1 arttığında genç kadın işsizlik \%1,624 artarken, erkeklerde ortalama ilk evlenme yaşı \%1 arttığında genç erkek işsizliği \%1,002 azaltmaktadır.

Tablo 3: Panel Regresyon Tahmini.

\begin{tabular}{lccc}
\hline Değişkenler & Toplam Genç İşsizlik & Genç Kadın İşsizliği & Genç Erkek İşsizliği \\
\hline $\ln \pi$ & $-0.147^{\mathrm{a}}$ & $0.142^{\mathrm{b}}$ & $-0.155^{\mathrm{a}}$ \\
$\ln y$ & $-0.198^{\mathrm{a}}$ & $-0.144^{\mathrm{b}}$ & $-0.233^{\mathrm{a}}$ \\
$\operatorname{lncoh}$ & $0.066^{\mathrm{a}}$ & - & - \\
$\ln w c o h$ & - & $0.083^{\mathrm{a}}$ & - \\
$\ln m c o h$ & - & - & $0.043^{\mathrm{b}}$ \\
$\ln i m$ & $0.101^{\mathrm{b}}$ & $0.173^{\mathrm{c}}$ & $0.097^{\mathrm{a}}$ \\
$\ln w m a g e$ & - & $1.624^{\mathrm{a}}$ & - \\
lnmmage & - & - & $-1.002^{\mathrm{a}}$ \\
\hline
\end{tabular}

Not: Tahminler sabit terim ve bir gecikme ile gerçekleştirilmiştir.

${ }^{\mathrm{a}}{ }^{\mathrm{b}} \mathrm{ve}^{\mathrm{c}}$ indisleri surasıyla $\% 1, \% 5$ ve $\% 10$ seviyesinde anlamlılığ 1 simgelemektedir.

\section{Politika Çıkarımları ve Sonuç}

Çalışmada, Türkiye'de bölgesel genç işsizlik dinamikleri ve bu dinamiklerin cinsiyete göre değişkenliğinin incelenmesi amaçlanmaktadır. Bu amaçla 2014-2019 döneminde İBBS-2 düzeyinde yer alan 26 bölgenin verileri, panel veri tahmin yöntemiyle analize tabi tutulmuştur. Analiz sonuçlarına göre bölgesel kişi başı gelirdeki artışlar hem toplam genç işsizliği, hem de cinsiyete göre genç işsizliği azaltmaktadır. Bölgelerin aldıkları göç oranındaki artış her üç kategorideki genç işsizlik oranlarını artırmaktadır. Benzer şekilde, hem Türkiye genelinde hem de cinsiyet bazında işgücü içerisindeki genç işgücünün artış1 genç işsizlik oranlarını artırmaktadır. Ayrıca, gelir, kohort büyüklüğü ve göç değişskenlerinin katsayıları cinsiyet açısından değerlendirildiğinde, belirleyicilerin genç kadın işsizliği üzerindeki olumsuz etkisinin genç erkeklerdeki etkisinden daha güçlü olduğuna dikkat çekmektedir. Genç işsizlik belirleyicilerinin cinsiyet bazında değişken olduğunu ortaya koyan en önemli kanıtlar ise, enflasyon oranı ve ortalama ilk evlenme yaşı değişkenlerinin etkilerinden gelmektedir. Buna göre, hem enflasyon oranındaki hem de ilk evlenme yaşındaki artış genç erkek işsizliğini azaltırken genç kadın işsizliğini artırmaktadır. 
Enflasyon oranındaki artışların genç kadın işsizliğini arttırması, fiyat artışına sebep olan bölgesel talep artışının bölgesel üretim hacmini artırması ve bunun sonucunda meydana gelen bölgesel işgücü talebinin erkek işgücü (veya yetişkin kadın işgücü) tarafından karşılandığı şeklinde yorumlanabilir. Ortalama ilk evlenme yaşının artmasıyla genç erkek işsizliğinin aksine genç kadın işsizliğinin artması ise, ortalama evlenme yaşı arttıkça hem kadınların hem de erkeklerin işgücü piyasasına girdiği; ancak erkeklerin istihdam edilirken kadınların iş aramaya devam ettiği şeklinde yorumlanabilir ${ }^{6}$.

$\mathrm{Bu}$ çalışmanın bulgularından yola çıkarak politika yapıcılara öneriler sunmak mümkündür. Öncelikle çalışma, çözüm önerilerinin bölgesel bazda geliştirilmesi gerekliliğine işaret etmektedir. Bölgelerin kendilerine has özelliklerinin göz ardı edilip, gençlerin işgücü piyasasına entegrasyonuna yönelik politikalarda genelleştirmeye gidilmesi, sorunun çözümünü daha da zorlaştırabilir. Bu noktada, bölgesel niteliklere uygun istihdam politikaları belirlenmeli ve bölgelerdeki güçlü sektörler ön plana çıkartılmalıdır. Yapısal problemlerin çözümünde daha etkili olduğu bilenen makro politikalarla birlikte uygulanacak mikro politikaların, bölgesel işsizliğin azaltılmasında çok önemli bir rol oynayacağı açıktır. Özellikle yeni işgücü için yeterli istihdam alanlarının sağlanması, uygulanacak aktif istihdam politikalarının etkinliği açısından oldukça mühimdir. Bununla birlikte, istihdam edilecek genç nüfusun iş güvencesini (istihdamın kalıcılığını) sağlayacak politikalar geliştirilmesi ile kamunun istihdam yaratan özel sektör girişimlerini desteklemesi ve bölgesel olarak önemli sektörlerde faaliyet gösteren firmalara teşvikte bulunması, sorunun bölgesel ölçekte çözümüne katkı sağlayacaktır.

Ayrıca çalışmada, genç işsizliği etkileyen dinamiklerin cinsiyete göre farklılık gösterdiği tespit edilmiştir. Buna göre politika yapıcılar, işgücü piyasasında genç işsizliği çözmeye yönelik geliştirecekleri politikalarda cinsiyet faktörünü göz ardı etmemelilerdir. Örneğin enflasyon değişkenine ait bulgular, işsizlikle mücadelede uygulanacak genişletici politikaların genç erkeklerin aksine genç kadınlarda işsizliği artırabileceğini göstermektedir. Benzer şekilde kişi başı gelir, kohort büyüklüğü ve iç göç dinamiklerinin cinsiyet bazında etkileri değerlendirildiğinde, uygulanabilecek istihdam politikalarının genç kadınlara kıyasla genç erkeklerde işsizliği daha fazla azaltacağı görülmektedir. Ayrıca evlenme yaşındaki artışın her iki cinsiyette de işgücüne katılımı artırırken sadece erkeklerde işsizlik oranını azaltması, işgücü piyasasında erkeklerin daha fazla tercih edildiğinin bir diğer göstergesi olarak değerlendirilebilir. Bu nedenle kadın-odaklı istihdam politikaları daha fazla

\footnotetext{
${ }^{6} \mathrm{Bu}$ yorumun doğruluğunu sınamak için kadınlar için bölgesel ortalama ilk evlenme yaşı değişkeninin genç kadınlarda bölgesel işgücüne katılma oranı üzerindeki etkisi, erkekler için bölgesel ortalama ilk evlenme yaşı değişkeninin ise genç erkeklerde bölgesel işgücüne katılma oranı üzerindeki etkisi ayrı ayrı analiz edilmiştir. Her iki regresyon katsayısı da pozitif ve \%1 seviyesinde istatistiksel olarak anlamlı bulunmuştur (tahmin edilen katsayılar: kadınlar için 1,029; erkekler için 1,174)
} 
desteklenerek, bulguların işaret ettiği dışlama etkisi hafifletebilir. Bu kapsamda, genç kadınlara yönelik hem beşeri sermaye arttırıcı (kaliteli eğitim odaklı okullaşma oranının artırılması, yeni teknolojiye kolay adaptasyonu sağlayacak mesleki eğitim seminerlerinin yaygınlaştırılması vb.) hem de piyasaya girişi kolaylaştıracak (genç kadın istihdam teşviki, okul öncesi eğitimde erişilebilirliğin arttırılması vb.) politikalar benimsenerek genç kadınların işgücü piyasasına entegrasyonu hızlandırılmalıdır.

$\mathrm{Bu}$ çalışmaların bulgularından yola çıkarak gelecekte bu konuda çalışma yapacak araştırmacılara öneriler sunmak da mümkündür. Türkiye'de sadece iktisadi değil ortalama ilk evlenme yaşı gibi demografik faktörlerin de genç işsizlik üzerinde etkili olduğunun tespiti, modele eğitim durumu, hane başına düşen kişi sayısı, boşanma hızı gibi bölgespesifik değişkenlerin de eklenerek analizin derinleştirilebilmesine zemin hazırlamıştır. Ayrıca, zaman serisine ait gözlem sayısının daha uygun olduğu paneller, yatay kesitlere ait bulgular üzerinden sonuçların bölgeler arasında nasıl farklılaştığını inceleyebilir ve bölge bazında daha belirgin politika çıkarımlarında bulunabilirler.

Hakem Değerlendirmesi: Dış bağımsız.

Çıkar Çatışması: Yazarlar çıkar çatışması bildirmemiştir.

Finansal Destek: Yazarlar bu çalışma için finansal destek almadığını beyan etmiştir.

Peer-review: Externally peer-reviewed.

Conflict of Interest: The authors have no conflict of interest to declare.

Grant Support: The authors declared that this study has received no financial support.

\section{Kaynakça/References}

Anyanwu, J. (2014). Does intra-african trade reduce youth unemployment in Africa? African Development Review, 26(2), 286-309.

Ar1, E., ve Y1ldı, A. (2017). Examination of affecting variables for youth unemployment with cointegration analysis. Alphanumeric Journal, 5(2), 309-316.

Awad, A. (2019). Economic globalisation and youth unemployment: evidence from African countries. International Economic Journal, 33(2), 252-269.

Balcı İzgi, B., ve Konu, A. (2019). Genç işsizliğini belirleyen unsurlar: Brics ülkeleri ile Türkiye panel ardl uygulaması. Dokuz Eylül Üniversitesi Sosyal Bilimler Enstitüsü Dergisi, 21(1), 95-112.

Bayrak, R., ve Tatlı, H. (2016). Short and long term analysis of some factors effecting youth unemployment in Turkey. Theoretical \& Applied Economics, 23(3), 229-242.

Borjas, G. J. (1994). The economics of immigration. Journal of Economic Literature, 32(4), 1667-1717.

Bölükoğlu, A. (2018). Female employment as a reserve army of labor: Case of Turkey, 1988-2013. Ekonomi, Politika \& Finans Araştırmaları Dergisi, 3(1), 50-67.

Brooks, P. K., \& Pradhan, M. (2015). Youth unemployment in Europe: Okun's law and beyond in the mechanics of a strong euro area: IMF policy analysis. International Monetary Fund.

Butkus, M., \& Seputiene, J. (2019). The output gap and youth unemployment: an analysis based on Okun's law. 
Economies, 7, 108, 1-17.

Choudry, M., Marelli, E., \& Signorelli, M. (2012). Youth unemployment rate and impact of financial crises. International Journal of Manpower, 33(1), 76-95.

Cvecic, I., \& Sokolic, D. (2018). Impact of public expenditure in labour market policies and other selected factors on youth unemployment. Economic Research-Ekonomska istraživanja, 31(1), 2060-2080.

Çelik, R., ve Arslan, I. (2018). Göç ve işsizlik arasındaki ilişki: ampirik bir uygulama. Sosyal Siyaset Konferansları Dergisi, 74, 65-75.

Çetinkaya, E. (2010). Genç işsizliğin teorik açıklamaları. Sosyal Siyaset Konferansları Dergisi, 58, 45-57.

Çondur, F., ve Cömertler Şimşir, N. (2017). Türkiye'de eğitim harcamaları, ekonomik büyüme ve genç işsizlik ilişkilerinin analizi. Uluslararası Bilimsel Araştırmalar Dergisi, 2(6), 44-59.

Demidova, O., \& Signorelli, M. (2012). Determinants of youth unemployment in Russian regions. Post-Communist Economies, 24(2), 191-217.

Didin Sönmez, F., ve Özerkek, Y. (2018). Türkiye'de bölgesel genç işsizliğin belirleyicileri. Marmara Üniversitesi İktisadi ve İdari Bilimler Dergisi, 40(2), 297-318.

Driscoll, J. C., \& Kraay, A. C. (1998). Consistent covariance matrix estimation with spatially dependent panel data. Review of Economics and Statistics, 80(4), 549-560.

Dunsch, S. (2016). Okun's law and youth unemployment in Germany and Poland. International Journal of Management and Economics, 49(1), 34-57.

Dünya Bankası Veritaban1, https://data.worldbank.org/indicator/SL.UEM.1524.NE.ZS?end=2019\&start=2014 (Erişim tarihi: 22.05.2020).

Erikli, S. (2016). Genç yoksulluğunun temel belirleyicileri: Eğitim ve düzgün iş. Gazi Üniversitesi İktisadi ve İdari Bilimler Fakültesi Dergisi, 18(1), 283-302.

Ghoshray, A., Ordóñez, J., \& Sala, H. (2016). Euro, crisis and unemployment: youth patterns, youth policies? Economic Modelling, 58, 442-453.

Gomez-Salvador, R., \& Leiner-Killinger, N. (2008). An analysis of youth unemployment in the euro area. ECB Occasional Paper, (89).

Göksel, İ. (2013). Female labor force participation in Turkey: the role of conservatism. Women's Studies International Forum, 41, 45-54.

Granger, C.W.J. \& Newbold, P. (1974). Spurious regressions in economics, Journal of Econometrics, 4, 111-120.

Greenwood, M. J., \& McDowell, J. M. (1986). The factor market consequences of US immigration. Journal of Economic Literature, 24(4), 1738-1772.

Günaydın, D., ve Çetin, M. (2015). Genç işsizliğin temel makroekonomik belirleyicileri: ampirik bir analiz. Pamukkale Üniversitesi Sosyal Bilimler Enstitüsü Dergisi, 22, 17-34.

Güney, A., ve Balkaya, E. (2018). Kamu harcamaları ve ticari açıklığın işsizlik ve genç işsizliğe etkisi. Sinop Üniversitesi Sosyal Bilimler Dergisi, 2(2), 49-74.

Harris, J. R., \& Todaro, M. P. (1970). Migration, unemployment and development: a two-sector analysis. The American Economic Review, 60(1), 126-142.

Im, K. S., Pesaran, M. H., \& Shin, Y. (2003). Testing for unit roots in heterogeneous panels. Journal of Econometrics, 115(1), 53-74.

Isengard, B. (2003). Youth unemployment: Individual risk factors and institutional determinants. A case study of Germany and the United Kingdom. Journal of Youth Studies, 6(4), 357-376.

Jean, S., \& Jiménez, M. (2011). The unemployment impact of immigration in OECD countries. European Journal of Political Economy, 27(2), 241-256. 
Jimeno, J., \& Rodriguez-Palenzuela, D. (2003). Youth unemployment in the oecd: demographic shifts, labour market institutions and macroeconomic shocks. ENEPRI Working Paper .

Kabaklarl1, E., ve Gür, M. (2011). Türkiye'de genç işsizlik sorunu ve ekonomik belirleyicilerinin uzun dönem eşbütünleşme analizi. 14. Uluslararası Iktisat Ögrencileri Kongresi, Erişim adresi: https://acikerisim.aku.edu.tr/ xmlui/bitstream/handle/11630/7371/Turkiye_de_Genc_Issizlik_Sorunu_ve_Ekono. pdf?sequence $=1 \&$ isAllowed $=y,($ Erişim tarihi: 23.05.2020).

Karahan Dursun, P. (2019). Doğrudan yabancı yatırımların eğitim düzeylerine göre genç istihdam üzerindeki etkisi: Türkiye örneği. Finans Politik \& Ekonomik Yorumlar, 56(649), 83-111.

Korenman, S. \& Neumark, D. (2000). Cohort crowding and youth labor markets: A cross-national analysis. In David Blanchflower and Richard Freeman, (eds.), Youth employment and unemployment in advanced countries (pp. 57-105). USA: Chicago University Press.

Levin, A., Lin, C. F., \& Chu, C. S. J. (2002). Unit root tests in panel data: asymptotic and finite-sample properties. Journal of Econometrics, 108(1), 1-24.

Lindbeck, A., \& Snower, D. J. (2001). Insiders versus outsiders. Journal of Economic Perspectives, 15(1), 165188.

Longhi, S., Nijkamp, P., \& Poot, J. (2006). The impact of immigration on the employment of natives in regional labour markets: a meta-analysis. Institute for the Study of Labour, Discussion Paper, 2044, 1-21.

Marelli, E., Choudhry, M. T., \& Signorelli, M. (2013). Youth and total unemployment rate: The impact of policies and institutions. Rivista Internazionale Di Scienze Sociali, 121(1), 63-86.

Moffat, J., \& Roth, D. (2014). Cohort size and youth unemployment in Europe: a regional analysis (No. 40-2014). Joint Discussion Paper Series in Economics.

O'higgins, N. (1997). The challenge of youth unemployment. International Social Security Review, 50(4), $63-93$.

Okun, A. M. (1962). Potential GNP: Its Measurement and Significance. In: Proceedings of the Business and Economic Statistics Section of the American Statistical Association. Alexandria, VA: American Statistical Association, 89-104.

Özer, U., ve Topal, M. (2017). Genç işsizliği, suç, göç, intihar ve boşanma düzeyleri ile ilişkili midir? Türkiye’den ampirik bir kanıt. Kırklareli Üniversitesi İktisadi ve İdari Bilimler Fakültesi Dergisi, 6(5), 50-63.

Pastore, F., \& Giuliani, L. (2015). The determinants of youth unemployment. a panel data analysis. Discussion Papers 2_2015. CRISEI, University of Naples" Parthenope", Italy.

Phillips, A. W. (1958). The relation between unemployment and the Rate of change of money wage rates in the United Kingdom, 1861-1957 1. Economica, 25(100), 283-299.

Sever, E., ve İğdeli, A. (2018). The determining factors of youth unemployment in developing countries: the case of Turkey. Uluslararasi Sosyal ve Ekonomik Bilimler Dergisi, 8(1), 75-83.

Şen, M. (2014). Trabzon`dan İstanbulıa Göç Edenlerin Sosyo-Ekonomik Analizi. Çalışma Dünyası Dergisi, $2(3) .46-61$.

Terzo, G., \& Giaconia, C. (2019). The socio-demographic determinants of youth unemployment in Italy: Evidences from national labour survey. EconWorld2018, Seville, Spain.

Todaro, M. P. (1969). A model of labor migration and urban unemployment in less developed countries. The American Economic Review, 59(1), 138-148.

Topcu, M. (2018). İşgücünün dışındaki kalabalık: ev işleriyle uğraşanların belirleyicileri üzerine bir analiz. Uluslararası Yönetim İktisat ve İşletme Dergisi, 14(3), 867-881.

Türkiye İstatistik Kurumu (TUIK) Veritabanı, (Erişim tarihi: 23.05.2020). 
Uluslararası Çalı̧̧ma Örgütü (ILO), https://www.ilo.org/global/lang--en/index.htm (Erişim tarihi: 22.05.2020). 